\title{
Inhibitors of collagenolytic enzymes in the serum of patients with chronic liver disorders
}

\author{
E J KUCHARZ \\ From the Department of Clinical Chemistry and Laboratory Diagnostics, Silesian School of Medicine, \\ Katowice, Poland
}

SUMMARY Inhibitory effect of serum on collagenolysis was studied in rat hepatic slices. Sera of patients with cirrhosis contained low concentrations of inhibitors. Higher concentrations were found in sera from patients with chronic active hepatitis and chronic persistent hepatitis, than in healthy individuals. It is suggested that changes of the serum inhibitory activity are responsible for the control of collagen degradation in the injured liver.

Chronic hepatic disorders are associated with accumulation of excess of collagen in the liver and hepatic fibrosis is important in the development of serious hepatic dysfunction. ${ }^{1-3}$ Collagen degrading enzymes in fibrotic hepatic tissue have been studied by numerous investigators. It is generally accepted that collagen degradation is raised under conditions of fibrosis. Increased activity of collagenase, ${ }^{45}$ collagen peptidase ${ }^{67}$ and collagenolytic cathepsin 89 has been described in the liver. It has been suggested that increased degradation of collagen is a defensive mechanism against fibrosis, but it is usually insufficient to successfully diminish the fibrotic process. ${ }^{8} 10$

The mechanism of accelerated degradation of collagen fibres in the liver is unclear. Degradation of collagen needs the controlled action of a group of specific enzymes capable of selectively cleaving this fibrous protein. It was found that non-specific proteolytic enzymes were able to activate collagenase - the main enzyme responsible for cleavage of collagen. The nature of this phenomenon is controversial. Proteolytic removal of the inhibitor from enzyme-inhibitor complex, or proteolytic activation of procollagenase, have been suggested. ${ }^{11} 12$

Recently increased activity of collagenase and changes of active to proteolytically activated enzyme ratio have been shown in hepatic tissue of rats chronically treated with carbon tetrachloride. ${ }^{10}$ In the present study an attempt was made to estimate the collagenolysis inhibitory activity of the blood serum from patients with chronic liver disorders.

Address for correspondence: Professor E J Kucharz, Department of Clinical Chemistry and Laboratory Diagnostics, Silesian School of Medicine, 40-036 Katowice, ul. Wita Stwosza 6/8, Poland.

Received for publication 4 January, 1984

\section{Methods}

PATIENTS

The study was done on 25 patients with hepatic cirrhosis (16 men: aged 43-61 years). Seventeen had chronic active hepatitis (eight women, nine men: aged 39-56 years), 23 had chronic persistent hepatitis (13 women, 10 men: aged $42-55$ years), and 30 healthy individuals (23 men: aged 32-53 years). Blood was collected at 7 am after 10 hours of fasting. The sera were diluted with physiological saline in order to normalise the total protein concentration to $50 \mathrm{~g} / 1$.

\section{ANALYSIS}

Wistar rat liver slices prepared as for tissue culture were used. ${ }^{13}$ It was found that these conditions were adequate for the investigations on living hepatic slices. ${ }^{14}$ Collagen degrading enzyme activity was measured as hydroxyproline concentration liberated from collagen by enzymes presented in hepatic slices. Collagen degradation was determined according to Sopata et al..$^{15}$ In brief, rat hepatic slices (500 $\mathrm{mg})$, reconstituted polymerised collagen fibres (5 $\mathrm{mg})$, serum $(0.5 \mathrm{ml})$ and $0.05 \mathrm{M}$ Tris- $\mathrm{HC} 1$ buffer $\mathrm{pH}=7.5$ containing $0.005 \mathrm{M} \mathrm{CaCl}_{2}$ and $0.2 \mathrm{M} \mathrm{NaCl}$ were incubated for $18 \mathrm{~h}$ at $37^{\circ} \mathrm{C}$. Control samples consisted of the same substances with potassium cyanate $(0.05 \mathrm{M})$ and collagenase inhibitor $\mathrm{N}$-methyl maleimide (NMM), 1.25 $\mu \mathrm{M}$. Control samples were used to allow for non-enzymatic liberation of hydroxyproline from collagen and to exclude the effect of the presence of hydroxyproline in the tested serum. Hydroxyproline was determined in the supernatant after acid hydrolysis with the 
method of Dróżdż et $a^{16}$ based on Stegemann's reaction. ${ }^{17}$ Similar estimations were carried out in the same mixture, though it did not contain serum.

The results were calculated as measured values minus control values (sample contained potassium cyanate). The following mean control values were obtained: normal subjects 0.012 ; cirrhosis 0.033 ; persistent hepatitis 0.018 ; active hepatitis 0.020 $\mu \mathrm{mol} / \mathrm{sample}$. The inhibiting activity was calculated as percentage of hydroxyproline enzymatically liberated from collagen substrate in the mixture with serum, compared with samples without serum. Each serum sample was measured in triplicate and the mean value was calculated.

Results are presented as mean \pm SEM. Statistical analysis was performed with Student's $t$ test.

\section{Results}

The measurements of inhibitory activity are in the Table. A significant decrease of inhibition was found in cirrhosis. By contrast, a significant rise was recorded in the patients suffering from chronic active or persistent hepatitis. Higher values were recorded in the patients with chronic active, than in those with chronic persistent hepatitis.

\section{Discussion}

Human plasma contains numerous inhibitors of proteolytic enzymes. Most of them are synthesised in the liver. It is believed that the inhibitors are produced as acute phase reaction to protect tissues against lysosomal enzyme-induced injury. ${ }^{18}$ Changes in the serum concentration of non-specific protease inhibitor have been described previously,

Table Inhibiting activity of serum on collagen degrading enzymes

\begin{tabular}{|c|c|c|c|}
\hline & \multicolumn{2}{|c|}{$\begin{array}{l}\text { Hydroxyproline release* } \\
\text { umol/sample }\end{array}$} & \multirow{2}{*}{$\begin{array}{l}\text { inhibition } \\
\%\end{array}$} \\
\hline & Without serum & With serum & \\
\hline $\begin{array}{l}\text { Healthy individuals } \\
\mathrm{n}=30\end{array}$ & $s 6 \cdot 21 \pm 0 \cdot 87$ & $2 \cdot 66 \pm 0.63$ & $57 \cdot 17 \pm 3 \cdot 42$ \\
\hline $\begin{array}{l}\text { Cirrhosis } \\
n=25\end{array}$ & $6 \cdot 28 \pm 0 \cdot 75$ & $4 \cdot 47 \pm 0.94$ & $28 \cdot 82 \pm 5 \cdot 41 \dagger$ \\
\hline $\begin{array}{l}\text { Chronic persistent } \\
\text { hepatitis } \\
n=23\end{array}$ & $6 \cdot 15 \pm 0 \cdot 74$ & $2 \cdot 11 \pm 1 \cdot 05$ & $65 \cdot 69 \pm 4 \cdot 75 \dagger$ \\
\hline $\begin{array}{l}\text { Chronic active } \\
\text { hepatitis } \\
n=17\end{array}$ & $6 \cdot 15 \pm 0 \cdot 81$ & $1 \cdot 77 \pm 1 \cdot 12$ & $71 \cdot 22 \pm 4.03 \dagger$ \\
\hline
\end{tabular}

* Obtained by calculating: determined values minus control containing sample potassium cyanate.

$\dagger \mathrm{p}<0.001$ compared with controls. but the results were contradictory. Normal concentrations of alpha 1-antitrypsin in cirrhotic patients was reported by Sharp et al, ${ }^{19}$ and Aschauer et al. ${ }^{20}$

Theodoropoulos et $a l^{21}$ and Bogdal et $a l^{22}$ described increased concentration of serum alpha 1-antitrypsin in chronic hepatic disorders. Alpha 1-antitrypsin does not inhibit collagenase. The specific inhibitor of collagenase was isolated from serum by Woolley et $a l^{23}$ and described as beta 1 -anticollagenase. The role of this protein in the control of collagen degradation is still unclear.

In the present study decreased inhibitory activity was found in sera from patients with cirrhosis. These changes were probably connected with hepatic cell failure. Increased inhibitory activity in sera from patients with chronic hepatitis can be explained as an acute-phase reaction to chronic inflammation.

It is difficult to determine the details of the described effect of sera upon collagen degradation, because substances originating from the liver samples and the sera acted simultaneously. The phenomena observed may depend on the action of the serum on proteolytic activation of collagenase, or on direct inhibition of the enzyme by serum proteins. Thus direct, or indirect mechanism can exist. Another limitation stems from the use of an exogenous substrate - the rat liver slices - for investigation of human sera. Substrate specificity of collagenase, as well as quantitative changes of the collagen fibres in the course of hepatic fibrosis, are still subjects of controversy. All these limitations have to be taken into consideration in the interpretation of the results.

The place of the present observations in the natural history of hepatic fibrosis is unclear. It is possible that the decreased serum inhibitory activity is connected with elevated collagen degradation in the liver.

This mechanism may act against collagen accumulation (hepatic self-defensive reaction) as was suggested previously. ${ }^{10}$ Further investigations, including studies with purified degrading enzyme preparations, are needed.

\section{References}

1 Popper H. Die Leberfibrose - Enstehung, Dynamik und klinische Bedeutung. Leber Magen Darm 1978; 8: 65-72.

2 Popper $\mathrm{H}$, Becker $\mathrm{K}$ eds. Collagen metabolism in the liver. New York: Stratton Intercontinental Medical Book Co; 1975.

3 Popper H, Piez KA. Collagen metabolism in the liver. Am J Dig Dis 1978; 23: 641-59.

4 Okazaki I, Miruyama K. Collagenase activity in ex- 
perimental hepatic fibrosis. Nature 1974; 252: 49-50.

5 Samba K, Kamegaya K, Oda M, Okazaki I. Hepatic fibrosis. In: Otaka Y, ed. Biochemistry and pathology of connective tissue. Stuttgart: Georg Thieme 1974; $249-76$.

6 Grasedyck K, Ropohl D, Szarvas F, Lindner J. Kollagen-peptidase-activität menschlicher Seren bei Lebercirrhose. Klin Wochenschr 1971; 49: 163-4.

7 Kucharz E, Dróżdż M, Obuchowicz E. Collagen peptidase in chronic liver disorders. Z Med LabDiagn 1981; 22: 307-13.

8 Kucharz E, Dróżdż M. Disturbances in collagen metabolism accompanied liver damage. 12th FEBS Meeting, Dresden 1978. Dresden: Biochemical Society of GDR, 1978. Abstracts p. 159.

9 Sakai T, Oda T, Yokono Y, Igarashi S, Suzuki H, Yoshitoshi Y. Collagenase-like peptidase activity in fibrotic liver tissue. Clin Chim Acta 1967; 15: 321-4.

10 Kucharz E. Clinical and experimental studies on collagen metabolism in hepatic disorders. 1984. Rev Roum Med Med Intern 1984; 22: 129-40.

11 Woolley DE, Evanson JM. Collagenase and its natural inhibitors in relation to the rheumatoid joint. Conn Tiss Res 1977; 5: 31-5.

12 Woolley DE, Evanson JM. Collagenase in normal and pathological connective tissue. Chichester: Wiley and Sons, 1980.

13 Kucharz E, Stawiarska B, Dróżdż M. Influence of antirheumatic drugs on the activity of collagenolytic cathepsin in hepatic slices culture. Acta Biol Med Ger 1982; 41: 39-46.

14 Stawiarska B, Kucharz E, Dróżdż M. Application of liver slices cultured in vitro for hepatotoxicity studies of antirheumatic drugs In: Kaiser R, Gabl F, Muller MM,
Bayer $\mathrm{M}$, eds. Proceedings of the XI international congress of clinical chemistry. Berlin-New York: Walter de Gruyter, 1982: 817-27.

15 Sopata I, Wojtecka-Lukasik E, Dancewicz AM. Solubilization of collagen fibrils by human leucocyte collagenase activated by rheumatoid synovial fluid. Acta Biochim Pol 1974; 21: 283-9.

16 Dróżdż M, Kucharz E, Szyja J. A colorimetric micromethod for determination of hydroxyproline in blood serum. Z Med Labortech 1976; 17: 163-71.

17 Stegemann H. Mikrobestimmung von Hydroxyprolin mit Chloramin T und p-Dimethylaminobenzaldehyd. $Z$ Physiol Chem 1958; 341: 311-5.

$18 \mathrm{Koj} \mathrm{A}$, Dubin A. On the hormonal modulation of acute-phase plasma protein synthesis in perfused rat liver. Acta Biochim Pol 1974; 21: 159-67.

19 Sharp HL, Bridges RA, Krivit W, Freier EF. Cirrhosis associated with alpha-1-antitripsin deficiency. $J$ Lab Clin Med 1969; 73: 934-8.

20 Aschauer R, Holzknecht F, Platzer S. Endogene Fibrynolyse-inhibitoren bei Lebercirrhosen. Klin Wochenschr 1973; 51: 1170-1.

21 Theodoropoulos G, Archimandritis A, Tsomi A, Chloros G, Rigatos G, Angelopoulos B. Serum trypsin inhibitory capacity and alpha 1-antitrypsin levels in liver cirrhosis and hepatoma. Acta Hepatogastroenterol (Stuttg) 1979; 26: 195-7.

22 Bogdal J, Cichecka K, Jedrychowski A. Zachowanie się alfa-1-antytrypsyny, alfa-2-makroglobuliny i aktywności antyplazminowej w chorobach wạtroby i dróg żólciowych. Pol Tyg Lek 1973; 28: 969-72.

23 Woolley DE, Roberts DR, Evanson JM. Small molecular weight beta-1 serum protein which specifically inhibits human collagenases. Nature 1976; 261: 325-7. 